\title{
Agrifood systems and the microbial safety of fresh produce: Trade-offs in the wake of increased sustainability
}

\author{
Christophe Nguyen-the a,*, Marc Bardin ${ }^{\mathrm{b}, 1}$, Annette Berard ${ }^{\mathrm{c}, 1}$, Odile Berge ${ }^{\mathrm{b}, 1}$, Julien Brillard ${ }^{\mathrm{a}, 1,2}$, \\ Véronique Broussolle $^{\mathrm{a}, 1}$, Frédéric Carlin ${ }^{\mathrm{a}, 1}$, Pierre Renault ${ }^{\mathrm{c}, 1}$, Marc Tchamitchian ${ }^{\mathrm{d}, 1}$, Cindy E. Morris ${ }^{\mathrm{b}}$ \\ a UMR408 SQPOV «Sécurité et Qualité des Produits d'Origine Végétale», INRA, Avignon Université, 84000 Avignon, France \\ b INRA, UR0407 Plant Pathology, F-84143 Montfavet, France \\ c EMMAH, INRA, Avignon Université, 84000 Avignon, France \\ d INRA, UR0767 Ecodéveloppement, 84000 Avignon, France
}

\section{H I G H L I G H T S}

- Measures taken to improve safety were assessed for their impact on sustainability.

- Fresh produce safety improvements may come at the expense of sustainability.

- Environment, food security and human health constituted the three domains of sustainability.

- Measures to improve safety should be adapted to each agrifood system.
Keywords:

Foodborne pathogens

Waste water

Wildlife
G R A P H I C A L A B S T R A C T

Citations in the Web of Sciences related to the three domains of sustainability in the case of fresh produce. Areas are proportional to the numbers of citations.

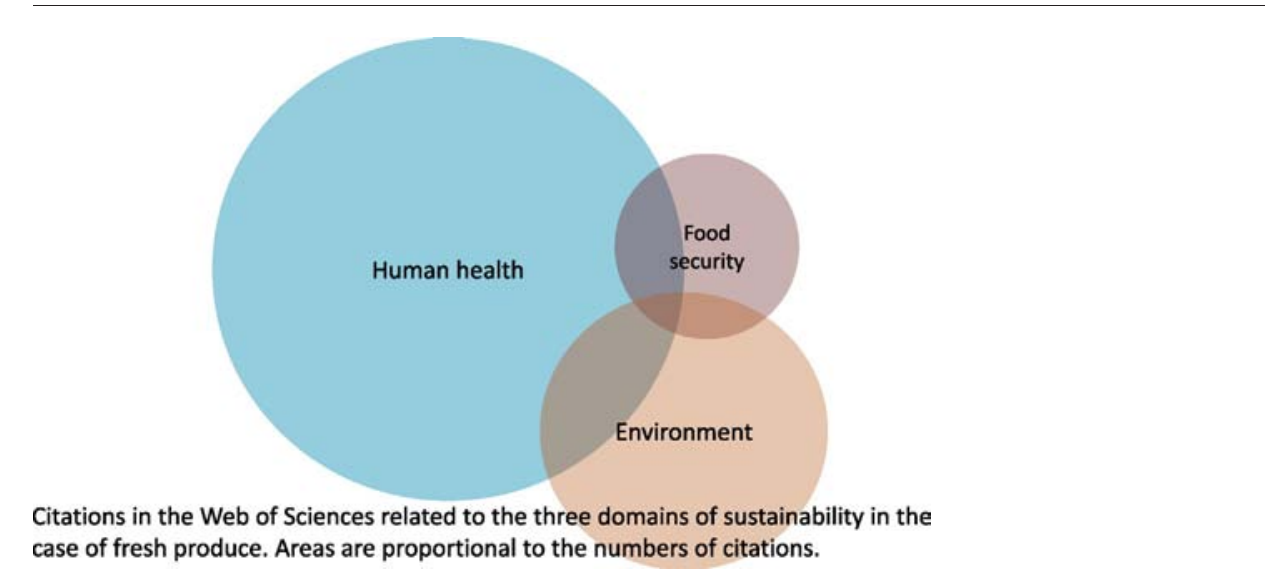

A B S T R A C T

Fresh produce has been a growing cause of food borne outbreaks world-wide prompting the need for safer production practices. Yet fresh produce agrifood systems are diverse and under constraints for more sustainability. We analyze how measures taken to guarantee safety interact with other objectives for sustainability, in light of the diversity of fresh produce agrifood systems. The review is based on the publications at the interface between fresh produce safety and sustainability, with sustainability defined by low environmental impacts, food and nutrition security and healthy life. The paths for more sustainable fresh produce are diverse. They include an increased use of ecosystem services to e.g. favor predators of pests, or to reduce impact of floods, to reduce soil erosion, or to purify run-off waters. In contrast, they also include production systems isolated from the environment. From a socio-economical view, sustainability may imply maintaining small tenures with a higher risk of pathogen contamination. We analyzed the consequences for produce safety by focusing on risks of contamination by water, soil, environment and live stocks. Climate change

* Corresponding author at: INRA, Site Agroparc, 228 route de l'Aérodrome, CS-40509, 84914 Avignon cedex 9, France.

E-mail addresses: christophe.nguyen-the@avignon.inra.fr (C. Nguyen-the), marc.bardin@avignon.inra.fr (M. Bardin), annette.berard@avignon.inra.fr (A. Berard), odile.berge@avignon.inra.fr (O. Berge), julien.brillard@univ-montp2.fr (J. Brillard), veronique.broussolle@avignon.inra.fr (V. Broussolle), frederic.carlin@avignon.inra.fr (F. Carlin), pierre.renault@avignon.inra.fr (P. Renault), marc.tchamitchian@avignon.inra.fr (M. Tchamitchian), cindy.morris@avignon.inra.fr (C.E. Morris).

1 These authors have equally contributed to this review.

2 Present address: INRA, Université de Montpellier, UMR1333, Diversity Genomes \& Interactions Microorganismes - Insectes, 34000 Montpellier, France. 


\section{Journal homepage : www.elsevier.com/locate/scitotenv}

Livestock

Organic farming

Climate change may increase the constraints and recent knowledge on interactions between produce and human pathogens may bring new solutions. Existing technologies may suffice to resolve some conflicts between ensuring safety of fresh produce and moving towards more sustainability. However, socio-economic constraints of some agri-food systems may prevent their implementation. In addition, current strategies to preserve produce safety are not adapted to systems relying on ecological principles and knowledge is lacking to develop the new risk management approaches that would be needed.

\section{Contents}

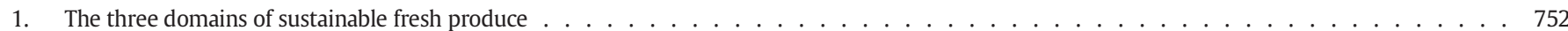

2. Risk factors for contamination of fresh produce . . . . . . . . . . . . . . . . . . . . . . . . . . . . . . . . . . . . . . . . .

3. Safety and the diversity of agrifood systems . . . . . . . . . . . . . . . . . . . . . . . . . . . . . . . . . 753

4. Questions raised by transitions toward more sustainability . . . . . . . . . . . . . . . . . . . . . . . . . . . 753

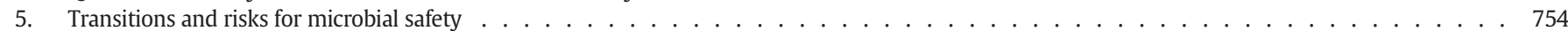

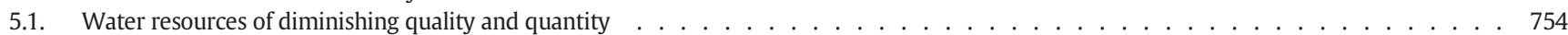

5.2. Soil management and microbial safety of fresh produce . . . . . . . . . . . . . . . . . . . . . . . . . . 754

5.3. Farm animals and produce safety issues . . . . . . . . . . . . . . . . . . . . . . . . . . . .

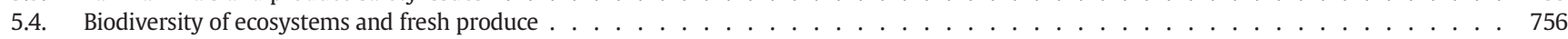

6. Fresh produce as active hosts of human pathogens $\ldots \ldots \ldots \ldots$

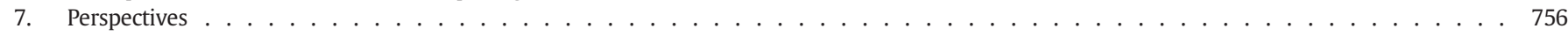

Appendix A. Supplementary data . . . . . . . . . . . . . . . . . . . . . . . . . . 756

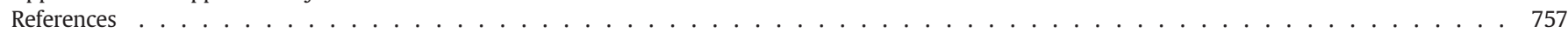

The growing world population, $+1.18 \%$ from 2010 to 2015 , (United_Nations, 2015), and the persistence of nearly 800 million chronically undernourished people (FAO et al., 2012, 2015) create a strong pressure to increase food production and food availability in many parts of the world. In developed countries, pressures come from the difficulties for farmers to make profits rather than from the concern over food security (Lal, 2008). Concomitantly, agriculture has been singled out as responsible for environmental damage through direct and indirect pollution, and through transformation of landscapes with their effects on biodiversity. As early as the 1980s (WCED, 1986), there were already several studies that investigated paths toward sustainable agriculture that respected the environment and secured food resources and farmers' incomes. However, agriculture must also produce foods of sufficient quality, in particular foods meeting the acceptable level of microbial safety expected by the public and by governments. Most foodborne illness comes from animal production, but as of the 1990s in the US (Lynch et al., 2009), and more recently in the EU (EFSA-Panel-onBiological-Hazards, 2013), the contribution of fresh produce to foodborne illness has rapidly increased. To integrate microbial food safety into the road map for more sustainable agriculture, we analyzed how measures taken to guarantee produce safety interact with other objectives and constraints in light of the diversity of fresh produce agrifood systems.

The present review does not address chemical hazards, which relate to risk factors different from those of microbial hazards.

\section{The three domains of sustainable fresh produce}

In 2010 the Food and Agriculture Organization defined "sustainable diets" as "those diets with low environmental impacts which contribute to food and nutrition security and to healthy life for present and future generations" (FAO, 2010). Hence, we identified three domains relevant to sustainable fresh produce: healthy for consumer (health), environmentally friendly production (environment), and production to meet the world demand (world) also referred to as food security. Health for consumers includes microbial safety, which is therefore part of sustainability and its health domain. However, in the present review for the sake of simplicity, we frequently use "sustainability" for "aspects of sustainability other than microbial safety". We established a list of keywords to retrieve publications in these domains from WOS (all databases since 1975, including conferences). The exact queries are detailed in Supplementary Data. For fresh produce, the three domains "health", "environment", or "world" yielded respectively 133422, 44331, 14250 citations. Publications concerning microbial safety represented $38 \%$ of the "health" domain. The overlap between each pair of the three domains represented 9752 citations for environment $\mathrm{X}$ health, 3532 for environment $X$ world, 5631 for health $X$ world and 1007 for environment $X$ health $X$ world. This suggests that the three domains are relatively disjoint. To verify the interactions between the three domains, we assessed the rate of cross citations, i.e. "do articles of domain A cite articles in domain B"? Only 5.8\% of the articles of the "health" domain cited at least one article of the two other domains "environment" or "world". "Environment" and "world" made less usage of the other domains with respectively $4.9 \%$ and $1.9 \%$ of articles citing at least one article from the two other domains. This confirms that the three domains are rather independent from one another, indicating a relatively low number of integrative studies with a global view of fresh produce sustainability. From the data base established for this analysis, we subsequently assessed the trends of research orientation in the interaction of sustainable production of fresh produce with microbial safety.

\section{Risk factors for contamination of fresh produce}

A large proportion of fresh produce is consumed raw, without microbiocidal treatment, and its microbial safety is a direct consequence of food chain conditions and practices. Epidemiological investigations of outbreaks, associated with testing of fresh produce for pathogens or indicators, have revealed some major risk factors linked to primary production and post-harvest conditions and practices. These include presence of livestock in the nearby environment of fresh produce production, contact with wild-life, contamination of soil with fecal material, fecal contamination of water used for irrigation or other agricultural purposes, lack of hygiene of handlers and of equipment, and inadequate washing procedures (Fig. 1) (EFSA-Panel-on-Biological-Hazards, 2013; Park et al., 2012). The impact of these risk factors on consumers' health 
Version définitive du manuscrit publiée dans / Final version of the manuscript published in :

Science of the Total Environment (2016), Vol. 562. p. 751-759, DOI: 10.1016/j,scitotenv.2016.03.241

\section{Journal homepage : www.elsevier.com/locate/scitotenv}

has been quantified and, because they are directly related to some farming practices, it has been possible to design some practical recommendations such as delaying the time between irrigation and harvest (Ottoson et al., 2011) and between the treatment of manure and the time of application of soil amendment (Franz et al., 2008b), as well as more hygienic post-harvest conditions (Danyluk and Schaffner, 2011).

\section{Safety and the diversity of agrifood systems}

The farming practices, and the prevailing risk factors, depend on the type of farm and farming system (e.g. size of tenures, mode of production, association with animal production), which in turn are a reflection of pressures and incentives from the more global agrifood system (Fig. 1) that includes a diversity of actors such as consumers, the distribution sector, the government. This latter has a strong influence for instance on the food safety management system, the environmental protection policy, and the economic environment of fresh produce farms. Concerning food safety management, agrifood systems have been classified as "traditional systems" with no traceability and with few established rules and regulations; as "structured systems" with some private standards and some traceability; or as "industrialized systems" with a significant degree of coordination and with private and public safety standards (McCullough et al., 2008). In developing countries, the development of "structured agrifood systems", for high value foodstuffs such as fresh produce (McCullough et al., 2008), occurred usually under pressure from large retailers (Reardon et al., 2008) and exporters (Narrod et al., 2008), resulting in a dual food system where modern practices yielding safer fresh produce coexist with traditional practices yielding fresh produce without implementation of safety measures. Similar distinction may also exist in developed countries with an industrialized system, where retailers can purchase fresh produce from large scale growers, pushing small and medium size growers to sell locally or directly to consumers (Parker et al., 2012), with cost being a barrier for implementing safety measures for these small and medium size farmers (Jacxsens et al., 2015).

In addition to cost, diversity of production on a small surface and rapid rotation made implementation of some good agricultural practices more difficult (Parker et al., 2012), such as deploying a delay time between manure application and planting to allow the natural decline of pathogens.

\section{Questions raised by transitions toward more sustainability}

New insight about the consequences of externalities of agricultural activities - and not only on production itself - has led to new modes and criteria of evaluation. The "Cross compliance" principle in the European Union Common Agriculture Policy, that links payments of subsidies to compliance by farmers with basic standards concerning the environment, the requirement for maintaining land in good agricultural and environmental conditions, is one example (EC, 2003, 2004). These trends are particularly striking for fruits and vegetables that are demanding both in terms of fertilizers and plant protection inputs. New forms of agriculture have developed or emerged to address the main stakes of sustainability, among which organic agriculture is probably the more emblematic (Crowder and Reganold, 2015). Production and consumption of organic products increased in the EU, the US and Japan (EC, 2010; Lohr, 2001) with fruits and vegetables being the main organic products consumed (EC, 2010; USDA, 2010). Organic apple production in the US, for example, was assessed as being the most economically and environmentally sustainable compared to conventional and integrated production (Reganold et al., 2001). Concerning microbial safety, some studies did not conclude that there were significant differences between organically versus conventionally grown produce (Smith-Spangler et al., 2012) whereas others found more frequent contamination with generic Escherichia coli, used as an indicator of fecal contamination, in organic produce (Mukherjee et al., 2004). However, organic farming is not a farming system in itself but can include several different types of systems. Comparison should be done at the level of specific practices, such as the use of fresh manure (aged less than 1 year) as fertilizer, which was correlated in the latter example with more risky produce for organic farms, but also for conventional farms (Mukherjee et al., 2004). The relevant question here would be what caused the use of fresh manure in some farms, and what constraints could hinder the use of older or properly composted manure, in both conventional and organic systems.

Other changes, not focusing specifically on organic production, are generally based on ecological principles to ensure soil fertility, crop health and yield, therefore relying on the support or the enhancement of biodiversity and the associated habitats (Hill and MacRae, 1995). Some changes reduce the quantities of products used (phytosanitary compounds, fertilizers...) while maintaining or enhancing their efficacy.

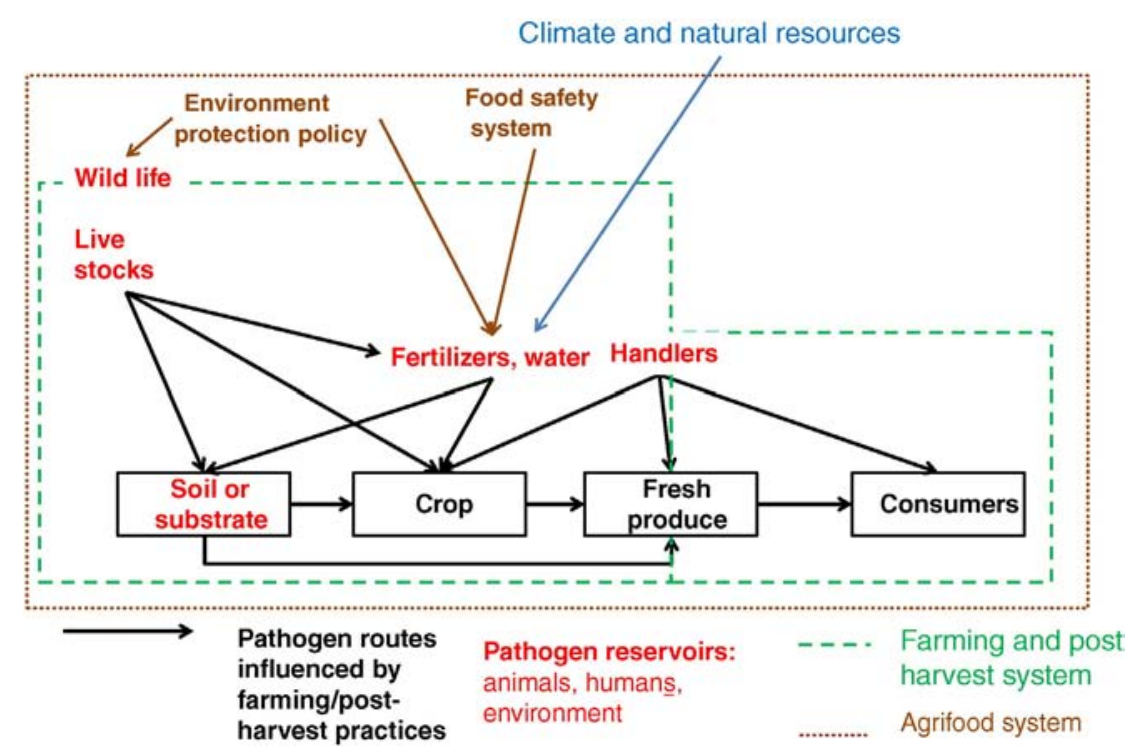

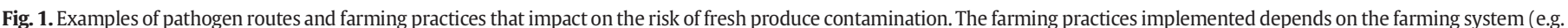

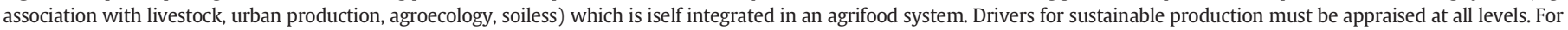

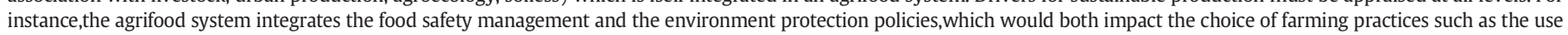
of organic fertilizers and some constraints such as the water quality. This latter is also dependent on the climate and the natural resource. 


\section{Journal homepage : www.elsevier.com/locate/scitotenv}

This has presumably minor impact on microbial safety of the produce. In contrast, substitution of e.g. mineral fertilizers by organic fertilizers, may open new risks of contamination by pathogenic bacteria depending on the methods of production of the organic fertilizers as discussed above (Mukherjee et al., 2004). Redesign implies a change in the system that, for example, allows for the introduction of habitats for beneficial insects, a closer association with livestock (EC, 2007), new soil preparation techniques to maintain fertility or prevent plant disease. This modifies the whole environment and landscape of fresh produce production with impacts on fresh produce safety that may be either direct (e.g. proximity with livestock that are potential reservoirs of pathogens), or indirect (e.g. increasing biodiversity leading to possible increase of contact with wild-life reservoirs of pathogens). A more radical example of redesign is cultivation in hydroponic, highly protected environments (as described for instance at http://www.toshiba.co.jp/about/press/ 2014_05/pr1501.htm accessed October 23rd 2015), and construction of vertical farms to economize land, water and avoid pesticides. Vertical farms may contribute to self-sufficiency in fresh produce for densely populated territories as Singapore (Anonymous, 2012) and in this respect may contribute to sustainability. However, their global impact on environment still need to be thoroughly assessed (Marris, 2010). Concerning safety, the risk of contamination with human pathogens should be reduced compared to traditional farms. However, absence of competitive microbiota in the growing medium of hydroponic systems may permit multiplication of human pathogens in case of their introduction into the system, e.g. via the seeds as observed in past outbreaks linked to sprouted seeds (EFSA-Panel-on-BiologicalHazards, 2011).

Although industrialized, modern agriculture in specialized rural areas permits economies of scale and a high efficiency in production and distribution (Green and Foster, 2005), maintaining a generalized access to fresh produce and maintaining a diversity of fresh produce farms are important elements for sustainability of food systems. This often goes toward local, urban or peri-urban production and direct farmer-to-consumer economic relationships (CEP, 2014; Lohr, 2001), with a risk of bypassing the quality and sanitary controls associated with the retailing system. In developing countries for instance, periurban production contributes to the supplies in fresh produce and to alleviate urban poverty (Hamilton et al., 2014), but was identified as a source of foodborne pathogens via irrigation with waste water (see Section 5.1 below), of heavy metals and polycyclic aromatic hydrocarbons released by industrial and urban activities (Hamilton et al., 2014).

The benefits of specific fresh produce production systems with regards to sustainability have been evaluated for environmental impacts, energy consumption, economic performance, social impacts (Bouzid and Padilla, 2014; Cellura et al., 2012; Reganold et al., 2001), but to our knowledge, no global sustainability assessments have included microbial safety. For this reason, the questions identified in this section are discussed below in the light of the factors contributing to the microbial risk of fresh produce (Table 1 ).

\section{Transitions and risks for microbial safety}

\subsection{Water resources of diminishing quality and quantity}

While irrigation is often the most important contributor to national water consumption (Jiménez and Asano, 2008), because of global change the world is facing increasing limitations of water resources (IPCC, 2012) in terms of quantity (Lazarova and Asano, 2005) and quality (Craun et al., 2006).

Wastewater reuse is a mean to cope with the depletion of conventional water resources (Angelakis and Durham, 2008; Asano, 2002) particularly in arid countries (Barker-Reid et al., 2010; Qadir et al., 2010) or in large urban areas where water goes mostly for direct human use (Van Rooijen et al., 2010). The reuse of wastewater as irrigation has other advantages such as fertilization that leads farmers in
Table 1

Examples of how some transitions toward more sustainability may increase the risk for contamination with foodborne pathogens.

\begin{tabular}{|c|c|}
\hline $\begin{array}{l}\text { Transition toward sustainability of } \\
\text { fresh produce production }\end{array}$ & $\begin{array}{l}\text { Increased risk factor for contamination with } \\
\text { foodborne pathogens }\end{array}$ \\
\hline \multicolumn{2}{|l|}{ Substituting: } \\
\hline $\begin{array}{l}\text { - Synthetic fertilizers by organic } \\
\text { fertilizers }\end{array}$ & $\begin{array}{l}\text { Produce growing on soil contaminated with } \\
\text { human or animal wastes. }\end{array}$ \\
\hline $\begin{array}{l}\text { - Surface/ground water by waste } \\
\text { water for irrigation }\end{array}$ & $\begin{array}{l}\text { Produce irrigated with un-properly treated } \\
\text { waste water }\end{array}$ \\
\hline \multicolumn{2}{|l|}{$\begin{array}{l}\text { Redesign of the production system } \\
\text { by: }\end{array}$} \\
\hline - Use of ecosystem services & $\begin{array}{l}\text { Produce in contact with wild-life carrying } \\
\text { zoonotic pathogens }\end{array}$ \\
\hline - Associations with livestock & $\begin{array}{l}\text { Produce contaminated with pathogens } \\
\text { released by farm animals }\end{array}$ \\
\hline $\begin{array}{l}\text { - Soil-less vertical farms and high } \\
\text { biosecurity farms }\end{array}$ & $\begin{array}{l}\text { Lack of microbial barriers against foodborne } \\
\text { pathogens }\end{array}$ \\
\hline \multicolumn{2}{|c|}{ Preserving local production by: } \\
\hline - Small tenures & $\begin{array}{l}\text { Implementation of food safety management } \\
\text { systems more difficult. }\end{array}$ \\
\hline $\begin{array}{l}\text { - Urban and peri-urban } \\
\text { production }\end{array}$ & $\begin{array}{l}\text { Implementation of food safety management } \\
\text { systems more difficult }\end{array}$ \\
\hline $\begin{array}{l}\text { - Producer to consumer } \\
\text { commercialization }\end{array}$ & By-passing food safety regulations \\
\hline - Self-production & By-passing food safety regulations \\
\hline
\end{tabular}

developing countries worldwide to prefer using untreated sewage rather than treated sewage (Keraita et al., 2008c). However, the use of waste water for irrigation may cause direct spraying of foodborne pathogens on fresh produce and may also contaminate the soil which would become a source of subsequent contamination for produce (EFSAPanel-on-Biological-Hazards, 2014). It may also cause preferential water flows in the soil (Wallach et al., 2005), which accelerate migration of pesticides, nitrogen and pathogens to ground water (Darnault et al., 2004; Stagnitti, 1999). Contaminated ground water would then represent a risk if used for agriculture or drinking water. Notably, several diarrheal outbreaks have been associated with wastewater-irrigated vegetables (WHO, 2006). One of the current challenges for several countries is to encourage the reuse of wastewater while preventing microbial risks. The absence of clear regulations or the deployment of regulations unsuitable for certain contexts can paralyze any initiative (Molle et al., 2012; Uyttendaele et al., 2015). Regulations should be based on quantitative microbial risk assessment (Hamilton et al., 2006) that take into account the natural decline of pathogens on fresh produce after irrigation (Stine et al., 2005). However peri-urban fresh produce production in developing countries is a good illustration of the benefits gained via a production situation that is microbiologically risky, and the difficulty to reduce the risk without a global approach to improve water resource quality and a better organization of the market (Fig. 2).

\subsection{Soil management and microbial safety of fresh produce}

Soil is a key compartment where processes that impact both food safety and farming practices are played out. Soil is not a normal habitat for the pathogens that cause most of the outbreaks linked to fresh produce (Salmonella, pathogenic E. coli), whose presence in this habitat results from fecal contamination. Manure and human excreta are potential sources of fecal human pathogens. Organic agriculture promotes the use of manure for fertilizing fresh produce to limit the use of synthetic fertilizers, to promote local recycling of animal by-products, to integrate livestock production and to provide the necessary organic matter and nutrients to cultivated land (EC, 2007). Fertilization by animal wastes is also a practice of conventional farming (Ozores-Hampton, 2012). Overall, the incentive for using manure at the farm level is the increase in soil content in organic matter to protect soil and increase yields (Jacobsen et al., 2012). It can also increase soil carbon sequestration thereby reducing green-house gas emissions (Ryals et al., 2014). 


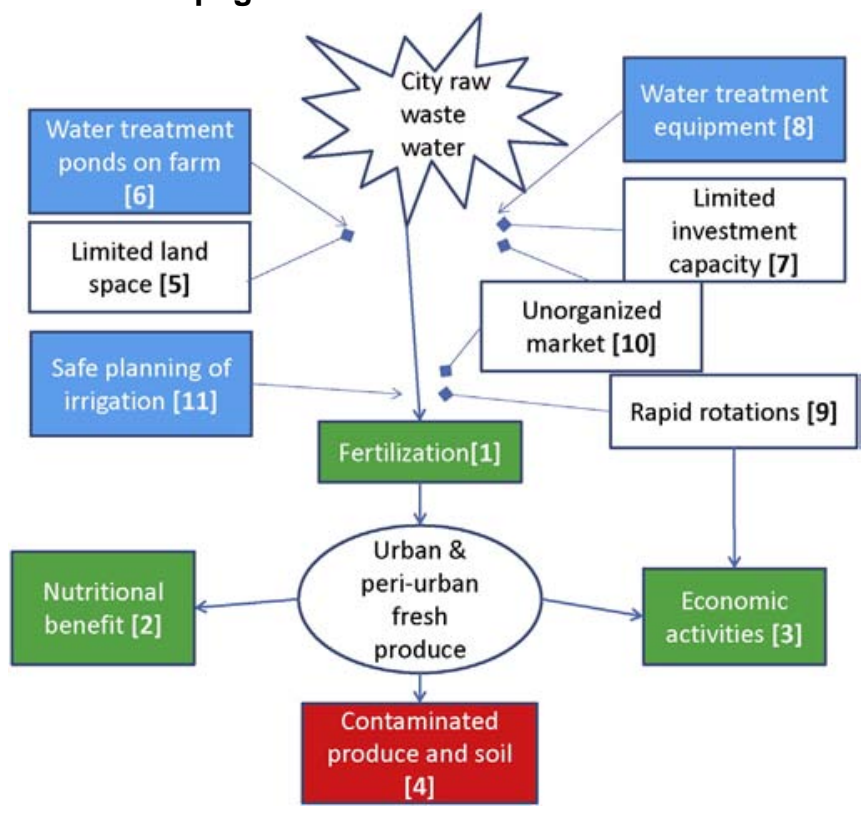

Fig. 2. Risk (red box) and benefits (green boxes) of urban fresh produce farms using raw waste water and difficulties (white boxes) for implementing measures to reduce the risks (blue boxes) in West Africa. Numbers in parentheses refer to the following comments. Urban or peri-urban fresh produce production in developing countries is particularly exposed to poor quality irrigation water (Levasseur et al., 2007), with a frequent use of shallow wells, polluted surface water or waste water. Using raw waste water is disapproved in some countries but very common in others (Hamilton et al., 2014). Raw waste water is widely used because it is easily available and also provides fertilization [1] (Hamilton et al., 2014). However, urban and peri-urban fresh produce represents both an important nutritional benefit [2] for the urban population (in western Africa $60 \%$ to $90 \%$ of fresh produce consumed are produced in or around the cities (Levasseur et al., 2007)) and a significant source of income [3] for many urban citizens (Hamilton et al., 2014). In particular, rapid rotations permit several crops a year [9] offering for both producers and sellers, a quick return for a limited initial investment (Hamilton et al., 2014). Fresh produce grown in such ways are often contaminated [4] with e.g. helminthes eggs (Amoah et al., 2006; Keraita et al., 2008a), as well as soil, as a consequence of repeated application of polluted water (Keraita et al., 2007a). Several constraints hamper strategies to reduce microbial risk. The limited land space available [5] proscribes the installation of on-farm water treatment ponds [6] (Keraita et al., 2008a); the limited investment capacity of the farmers [7] prohibits the acquisition of efficient water treatment systems [8] or drip irrigation equipment that would reduce contamination of the produce (Keraita et al., 2007a); the need for intensive production [9] and the lack of organized marketing systems [10] makes a safe planning of irrigation difficult [11], such as interrupting irrigation with unsafe water a few days before harvest (Keraita et al. 2007b). In addition, the market for this urban production lack commercial incentive for safer production practices (Keraita et al., 2008b; Levasseur et al., 2007).

Treatments to inactivate microbial pathogens, such as thermophilic composting, can be a way to resolve the compromise between the benefits of using manure for production of fresh produce and the risks for consumer safety (Burton, 2009; Martens and Bohm, 2009). Simple ageing of manure or animal slurries without proper control of its temperature does not provide a reliable reduction of human pathogens (Berry et al., 2013). For instance, frequencies of zoonotic pathogens in fresh and stored manures or slurries were similar (Hutchison et al., 2004). In addition, the application of manure to soil is not always regulated. In the EU, for example, regulation concerns only processed manure placed on the market and not raw manure used locally (EC, 2011). This latter is regulated at the national level, with emphasis most often on protection of water resources rather than on produce safety. Anaerobic digestion of animal effluents, usually co-digested with other wastes, produces biogas and is encouraged in many countries, by financial incentives to farmers, as a source of renewable energy (Igliński et al., 2012; Pantaleo et al., 2013). Anaerobically digested manure is likely to increase, with a main end-use as land fertilizer. However, anaerobic treatments of manure might be less efficient than aerobic treatments in inactivating pathogens, as illustrated, for instance, by E. coli and Salmonella that survived better in anaerobic than in aerobic manure (Semenov et al., 2011). In addition, the efficacy of anaerobic digestion to eliminate zoonotic pathogens depends on the technology used, on the treatment of the digestion end products and on the nature of the pathogen (Burton, 2009; Martens and Bohm, 2009). The choice of the technology interacts with other factors such as the density of animal farms and the scale of the treatment plant (Pantaleo et al., 2013), and the fertilizer value expected for the digestion end-products (Möller and Muller, 2012). The consequences on the risk for produce that could be fertilized with digester residues are difficult to anticipate. Human excreta can be spread on soil after treatments, in the framework of tight regulations developed to protect consumer safety as e.g. in the US (http://water.epa.gov/scitech/wastetech/biosolids/503pe_index. cfm accessed on October 23rd 2015), but are also commonly used with no, or minimal treatments, in some developing countries where they represent a valuable source of fertilizers for many crops, including fresh produce (Hamilton et al., 2014). The path toward sustainable fresh produce should include development of efficient sanitizing treatments for animal and human wastes as a source of fertilizers, adapted to the socio-economic situation.

Green manure and cover crops are alternative or complementary sources of organic matter for agricultural soil and can reduce weeds, soil erosion and run-off of fertilizers caused by rain (Smukler et al., 2012). As no plant species has so far been identified as the main reservoir of foodborne pathogenic bacteria, green manure should not represent a direct risk for crop safety. Indirectly, ubiquitous pathogens such as $L$. monocytogenes may benefit from the presence of decaying plant tissues (Weis and Seeliger, 1975). Among green manure, cruciferous species have been proposed as alternatives to pesticides in the fight against weeds and soilborne plant diseases through the production of glucosinolates (Haramoto and Gallandt, 2004; Vaughn and Boydston, 1997). These compounds also have broad antibacterial activity against human foodborne pathogens, but the impact of crucifer green manure on their survival in soil needs to be investigated.

Preserving or increasing the soil microbiota, in terms of diversity and biomass, is a major objective of sustainable agriculture. It has an important positive impact on yields, in particular by reducing soil born plant diseases (Chaparro et al., 2012; Singh et al., 2011). This can implies no ploughing systems, organic amendments and cover crops (Nair and Ngouajio, 2012). Increasing the diversity of soil microbiota contributes to antagonism against human pathogens (van Elsas et al., 2012). As a result of the greater microbial diversity and activity in organically managed soils, use of animal manures on those soils poses less risk of pathogen transmission than on conventional soils (Franz et al., 2008a). Survival of Salmonella in plant tissues is reduced when plants are grown in organic rather than in conventional soils (Gu et al., 2013). This shows the dual impact of organic amendments, a potential source of pathogens if not adequately processed, but also having the possibility to contributing antagonists of pathogens in the soil.

\subsection{Farm animals and produce safety issues}

According to EU regulations on organic farming (EC, 2007) "livestock production is fundamental to the organization of agricultural production on organic holdings", livestock being a source of organic fertilizers on the farm. Associating livestock and plant production may have other benefits. In small farms from subtropical countries association of livestock with crops improves usage of environmental resources as well as the economic resilience of the farms compared to crops alone (Wright et al., 2012). In the US, an experimental study tested the efficiency of animal power on small-scale vegetable production and found a similar financial return, with a higher energy efficiency for systems using oxen compared to systems using small tractors (Mulder and Dube, 2014). Introducing chickens in orchards may also provide multiple services such as fertilization, pest and weed control (Rosen, 2012). 


\section{Journal homepage : www.elsevier.com/locate/scitotenv}

Proximity of animal production to fresh produce fields has often been associated with foodborne outbreaks. Pathogens can be transferred to the fresh produce within a mixed animal/produce farm (Hilborn et al., 1999; Mshar et al., 1997) and at a wider scale after transport by water (Soderstrom et al., 2008) or wild life (Jay et al., 2007). Safety of fresh produce is presumably easier to control in areas with no, or little, animal production, although areas free of contamination from livestock reservoirs may be difficult to define. Reduction of the prevalence of zoonotic pathogens in farm animals would be necessary to permit a safe association of animals and fresh produce. This has been almost achieved in the EU for Salmonella Enteritidis and poultry (EFSA and ECDC, 2015), but in this example, how the measures implemented are compatible with the practices proposed for the association of poultry and produce should be evaluated.

In hydroponic vegetable production associated with fish farming, vegetables benefit from nutrients released by the fish while reducing water pollution. This represents a new and yet unexplored risk of transmission of zoonotic pathogens to consumers. Systems described to date range from very simple ones with vegetables floating on the fish tanks (Liang and Chien, 2013), to more sophisticated systems with filtration and UV treatment of the water (Petrea et al., 2013).

\subsection{Biodiversity of ecosystems and fresh produce}

The protection of biodiversity and the ecosystem is a global goal in itself for sustainable agriculture, and it is translated in certain guidelines such as EC reg 1107/2009 (EC, 2009) which states that plant protection products "shall have no unacceptable effects on the environment, [...] on non-target species, [...] on biodiversity and the ecosystem" (Nienstedt et al., 2012). Biodiversity can be preserved by managing uncultivated areas within or aside agricultural land (viz. land sharing vs. land sparing) (Fischer et al., 2008; Hodgson et al., 2010; Hulme et al., 2013), but land sharing offers a better use of the ecosystem services, by favoring species that are antagonistic to or predators of pests, or by reducing the impact of floods, reducing soil erosion or purifying runoff waters (Lahmar et al., 2012; Paetzold et al., 2010). In particular, climate change may increase extreme climatic events, leading to an urgent need for farming systems that protect soil and fields from flooding or erosion (IPCC, 2012). This can take the form of agroforestry associating trees with other crops including fresh produce (USDA, 2011), and multifunctional landscapes associating cultivated areas and nature conservation zones. However, wild life has been shown to carry foodborne pathogens such as Salmonella and pathogenic E. coli (Ferens and Hovde, 2011; Leopoldo et al., 2008). The proximity of wild-life or its ingress into fresh produce farms, packing and processing plants, has been confirmed or suspected as the cause of several foodborne outbreaks (Cook et al., 1998; Jay et al., 2007; Laidler et al., 2013; Parish, 1998; Sagoo et al., 2003; Sivapalasingam et al., 2004). Increasing biodiversity and the presence of wild life reservoirs close to fresh produce production may increase risks for consumers. In this respect, land sparing should reduce contact between fresh produce production and wild life reservoirs of pathogens. The concomitant reduction of some of the services brought by the ecosystems, such as predators of pests, can be artificially re-introduced to the production system as currently done in greenhouses. Conversely, fighting against wild life in agricultural zones in response to recommendations to improve fresh produce safety may imply destruction of non-crop plants and increasing surfaces of bare ground, which may come into conflict with environmental protection (Stuart, 2008) because of increased erosion, agriculture chemical run-off and enhanced pollution of the downstream coastal waters (Stuart, 2010).

In the case of production systems that facilitate close association between wild life and fresh produce, the question is the role of wild life in contamination of produce with foodborne pathogens. For a given wild life species, pathogen and farm production system, results from different studies have been conflicting, leading to the conclusion that there is no role of the wild life species (Gaukler et al., 2009) or alternatively that the wild-life species was the most important factor contributing to the contamination (Carlson et al., 2011). Hence, the question remains if wild life is the primary reservoir of a pathogen or only a vector of its transmission from another reservoir. For instance, seagulls were found to be contaminated with Campylobacter spp. when feeding on wastes (Ramos et al., 2010) and starlings were suspected to disseminate pathogenic E. coli from cattle farms (Williams et al., 2011). In the 2006 EHEC outbreak in the US from contaminated spinach (Jay et al., 2007), feral swine were the most likely cause of contamination of the spinach crop, but they possibly became contaminated via contact with nearby cattle farms. In such a case, corrective actions targeting the primary reservoir of the pathogen (e.g. cattle) would be more feasible and efficient than efforts to control wild life. However, some wild life species are known to carry specific strains of foodborne pathogens and to be the authentic reservoirs. Their role as reservoirs can be in stark contrast to the ecosystem services that they are expected to provide. For example, birds and bats were shown to have important roles in limiting the development of pests (Maas et al., 2013) but are also likely to transmit zoonotic diseases. For wild life that are sources of zoonotic pathogens and whose presence in the fresh produce fields is not wanted, studies on the permeability of the frontier between wild and cultivated areas (frequency of encounters, the types of animals that cross-over, how management practices encourage or discourage this) should be conducted.

\section{Fresh produce as active hosts of human pathogens?}

To date, management of fresh produce safety has mostly addressed the plant as a passive vector of human pathogens. However, interaction between fresh produce and human pathogens might be more complex with plant defense response pathways regulating colonization by human pathogens in an endophytic state (Fletcher et al., 2013). For instance, colonization by Salmonella is at least partly regulated by the plant defense response pathways in Medicago sp. (Iniguez et al., 2005) and as a function of plant genotype for lettuce (Klerks et al., 2007) and tomato (Barak et al., 2011). In the latter case, differences in susceptibility of tomato cultivars are associated with the type of leaf trichome. On different spinach cultivars, colonization patterns of $E$. coli 0157 were correlated with the topography of the leaf surface (Mitra et al., 2009). Certain lettuce cultivars showed varying levels of colonization by E. coli 0157 on the leaf surface (Quilliam et al., 2012). The cultivar effect on E. coli 0157 was also evident in the rhizosphere of plants, which suggests that cultivar-specific root exudates influence E. coli 0157. These studies open questions about the possibility that heritable plant traits may be included in plant breeding strategies to restrict colonization by human pathogens.

\section{Perspectives}

Microbiologically safe fresh fruits and vegetables are a valuable, common resource for producers, retailers, processors and consumers. Past examples of failures in preserving produce safety demonstrate the important consequences on consumer safety and on the economy of the production chain. A critical issue is how to implement regulations to preserve this resource. Resolving this issue implies finding a balance between i) the acceptable level of constraints on stakeholders, ii) the risk that these constraints eliminate some production systems which may have valuable benefits on society and iii) the differences in perception among stakeholders of what constitutes a safe fresh produce. Balancing these concerns may nevertheless create different levels of risk for consumers. Human pathogens are scarce on fresh produce compared to the sampling plans that can reasonably be applied for microbial testing of foods (EFSA-Panel-on-Biological-Hazards, 2014). Therefore the level of risk of a given food lot is better assessed by the efficiency of the safety control system applied during production than by testing 


\section{Version définitive du manuscrit publiée dans / Final version of the manuscript published in : \\ Science of the Total Environment (2016), Vol. 562, p. 751-759, DOI: 10.1016/j,scitotenv.2016.03.241 \\ Journal homepage : www.elsevier.com/locate/scitotenv}

the end product. Equivalence of different control systems in ensuring the same "appropriate level of sanitary protection" has been formalized in the framework of trade between different countries (Codex, 2005). A similar approach would be useful among different agrifood systems, highlighting their most relevant risk factors and the most appropriate ways to control them.

The first obstacle to such an approach is a lack of appropriate knowledge. For instance, preservation of fresh produce safety has so far mostly relied on reducing exposure of fresh produce to potential sources of pathogens. This tends to isolate the production system from the surrounding environment and is rather difficult to implement in agrifood systems using ecosystem services. Knowledge on the ecology of systems that could lead to certification of the safety of such production practices still needs to be developed. Knowledge of systems ecology has been built and deployed for environmental preservation, but the studies in this domain are poorly connected to the domain of healthy and safe produce.

Other difficulties come from socio-economic constraints of some agrifood systems that prevent implementation of known technologies that could resolve the dilemma between microbial safety and other aspects of sustainability. Whether solutions could come from innovative technologies or from innovations in the socio-economical organization would need to be resolved through multidisciplinary research.

We also need to address the possibility of decontamination treatments for fresh fruit and vegetables from production systems that would not reach an equivalent safety level. For instance, in the US irradiation of spinach and iceberg lettuce was approved in 2008 to control foodborne pathogens (Anonymous, 2008). However, such treatment raises issues of acceptability by consumers and the costs incurred may not be compatible with all production systems. The final use of fruits and vegetables in the food distribution chain, e.g. eaten raw versus heat treated, could also be adapted with regard to the microbiological risks that they could pose.

Overall, the diversity of fruit and vegetable agrifood systems needs to be defined as a prerequisite to formulating recommendations for assuring produce safety and the recommendations need to be adapted according to the range of systems. We bring attention to the need to make an assessment of the environmental and social benefits of the different fruit and vegetable agrifood systems and to compare these to the risks, costs and benefits of implementing control measures to ensure produce safety. This involves truly multidisciplinary issues in microbiology, agriculture, animal sciences, environment, biodiversity, social science and economy, especially in our context of climate change (Jacxsens et al., 2010). Wolf (2015) recently proposed a holistic approach illustrated by the issue of wetland preservation and the risk of mosquito transmitted diseases, which could be applied to foodborne diseases and sustainable fresh produce.

\section{Appendix A. Supplementary data}

Literature search strategy and the method used to analyze the citations. Supplementary data associated with this article can be found in the online version, at http://dx.doi.org/10.1016/j.scitotenv.2016.03.241.

\section{References}

Amoah, P., Drechsel, P., Abaidoo, R.C., Ntow, W.J., 2006. Pesticide and pathogen contamination of vegetables in Ghana's urban markets. Arch. Environ. Contam. Toxicol. 50 $1-6$.

Angelakis, A.N., Durham, B., 2008. Water recycling and reuse in EUREAU countries: trends and challenges. Desalination 218, 3-12.

Anonymous, 2008. Irradiation in the Production, Processing and Handling of Food. In: Food_and_Drug_Administration (Ed.), Federal Register/Vol. 73, No. 164/Friday, August 22, 2008/Rules and Regulations, pp. 49593-49603.

Anonymous, 2012. First Commercial Vertical Farm Opens in Singapore. AVA vision. AgriFood \& Veterinary Authority of Singapore (Available at http://www.ava.gov.sg/ publications 2012: 1-2. (accessed 2016.03.29)).
Asano, T., 2002. Water from (waste)water - the dependable water resource. Water Sci. Technol. 45, 23-33.

Barak, J.D., Kramer, L.C., Hao, L.Y., 2011. Colonization of tomato plants by Salmonella enterica is cultivar dependent, and Type 1 trichomes are preferred colonization sites. Appl. Environ. Microbiol. 77, 498-504.

Barker-Reid, F., Harper, G., Hamilton, A., 2010. Affluent effluent: growing vegetables with wastewater in Melbourne, Australia-a wealthy but bone-dry city. Irrig. Drain. Syst. 24, 79-94.

Berry, E.D., Millner, P.D., Wells, J.E., Kalchayanand, N., Guerini, M.N., 2013. Fate of naturally occurring Escherichia coli 0157:H7 and other zoonotic pathogens during minimally managed bovine feedlot manure composting processes. J. Food Prot. 76, 1308-1321.

Bouzid, A., Padilla, M., 2014. Analysis of social performance of the industrial tomatoes food chain in Algeria. New Medit. 13, 60-65.

Burton, C.H., 2009. Reconciling the new demands for food protection with environmental needs in the management of livestock wastes. Bioresour. Technol. 100, 5399-5405.

Carlson, J.C., Franklin, A.B., Hyatt, D.R., Pettit, S.E., Linz, G.M., 2011. The role of starlings in the spread of Salmonella within concentrated animal feeding operations. J. Appl. Ecol. 48, 479-486.

Cellura, M., Ardente, F., Longo, S., 2012. From the LCA of food products to the environmental assessment of protected crops districts: a case-study in the south of Italy. J. Environ. Manag. 93, 194-208.

CEP, 2014. Consommations et pratiques alimentaires durables: analyse de données nationales issues d'enquêtes d'opinion. In: PROSPECTIVE CDÉED (Ed.), 69 - Mai 2014. Ministère de l'Agriculture, de l'Agroalimentaire et de la Forêt, pp. 1-8.

Chaparro, J.M., Sheflin, A.M., Manter, D.K., Vivanco, J.M., 2012. Manipulating the soil microbiome to increase soil health and plant fertility. Biol. Fertil. Soils 48 , 489-499.

Codex, 2005. Food import and export inspection and certification systems. In: FAO (Ed.), Secretariat of the Codex Alimentarius Commission, Joint FAO/WHO Food Standards Programme. FAO, Rome. ISBN: 92-5-105321-9.

Cook, K.A., Dobbs, T.E., Hlady, G., Wells, J.G., Barrett, T.J., Puhr, N.D., et al., 1998. Outbreak of Salmonella serotype hartford infections associated with unpasteurized orange juice. JAMA 280, 1504-1509.

Craun, M.F., Craun, G.F., Calderon, R.L., Beach, M.J., 2006. Waterborne outbreaks reported in the United States. J. Water Health 4, 19-30.

Crowder, D.W., Reganold, J.P., 2015. Financial competitiveness of organic agriculture on a global scale. Proc. Natl. Acad. Sci. 112, 7611-7616.

Danyluk, M.D., Schaffner, D.W., 2011. Quantitative assessment of the microbial risk of leafy greens from farm to consumption: preliminary framework, data, and risk estimates. J. Food Prot. 74, 700-708.

Darnault, C.J.G., Steenhuis, T.S., Garnier, P., Kim, Y.J., Jenkins, M.B., Ghiorse, W.C., et al., 2004. Preferential flow and transport of Cryptosporidium parvum oocysts through the vadose zone: experiments and modeling. Vadose Zone J. 3, 262-270.

EC, 2003. COUNCIL REGULATION (EC) No 1782/2003 of 29 September 2003 establishing common rules for direct support schemes under the common agricultural policy and establishing certain support schemes for farmers and amending Regulations (EEC) No 2019/93, (EC) No 1452/2001, (EC) No 1453/2001, (EC) No 1454/2001, (EC) 1868/94, (EC) No 1251/1999, (EC) No 1254/1999, (EC) No 1673/2000, (EEC) No 2358/71 and (EC) No 529/2001. Off. J. Eur. Union L270, 1-69.

EC, 2004. Commission regulation (EC) N N $^{\circ}$ 796/2004 of 21 April 2004 laying down detailed rules for the implementation of cross-compliance, modulation and the integrated administration and control system provided for in of Council Regulation (EC) No 1782/ 2003 establishing common rules for direct support schemes under the common agricultural policy and establishing certain support schemes for farmers. Off. J. Eur. Union L141, 18-58.

EC, 2007. Council Regulation (EC) No 834/2007 of 28 June 2007 on organic production and labelling of organic products and repealing Regulation (EEC) No 2092/91. Off. J. Eur. Union L189, 1-23.

EC, 2009. REGULATION (EC) No 1107/2009 OF THE EUROPEAN PARLIAMENT AND OF THE COUNCIL of 21 October 2009 concerning the placing of plant protection products on the market and repealing Council Directives 79/117/EEC and 91/414/EEC. Off. J. Eur. Union L309, 1-50.

EC, 2010. An analysis of the EU organic sector. European Commission, Directorate-General for Agriculture and Rural Development, Organic Farming - Unit H.3. Economic Analyses of EU Agriculture - Unit L.2, Brussels.

EC, 2011. COMMISSION REGULATION (EU) No 142/2011 of 25 February 2011 implementing Regulation (EC) No 1069/2009 of the European Parliament and of the Council laying down health rules as regards animal by-products and derived products not intended for human consumption and implementing Council Directive 97/78/EC as regards certain samples and items exempt from veterinary checks at the border under that Directive. Off. J. Eur. Union L54, 1-254.

EFSA, ECDC, 2015. The European Union summary report on trends and sources of zoonoses, zoonotic agents and food-borne outbreaks in 2013. EFSA J. 13, 3991.

EFSA-Panel-on-Biological-Hazards, 2011. Scientific opinion on the risk posed by Shiga toxinproducing Escherichia coli (STEC) and other pathogenic bacteria in seeds and sprouted seeds. EFSA J. 9, 2424.

EFSA-Panel-on-Biological-Hazards, 2013. Scientific opinion on the risk posed by pathogens in food of non-animal origin. Part 1 (outbreak data analysis and risk ranking of food/pathogen combinations). EFSA J. 11, 3025.

EFSA-Panel-on-Biological-Hazards, 2014. Scientific opinion on the risk posed by pathogens in food of non-animal origin. Part 2 (Salmonella and Norovirus in leafy greens eaten raw as salads). EFSA J. 12, 3600.

FAO, 2010. Sustainable diets and biodiversity. In: Burlingame, B., Dernini, S., Nutrition and_Consumer_Protection_Division_FAO (Eds.), International Scientific Symposium. Biodiversity And Sustainable Diets, United Against Hunger. FAO, Rome, p. 309. 


\section{Version définitive du manuscrit publiée dans / Final version of the manuscript published in : Science of the Total Environment (2016), Vol. 562, p. 751-759, DOI: 10.101.6/j,scitotenv.2016.03.241 \\ Journal homepage : www.elsevier.com/locate/scitotenv}

FAO, WFP, IFAD, 2012. The State of Food Insecurity in the World 2012. Economic Growth Is Necessary But Not Sufficient To Accelerate Reduction Of Hunger And Malnutrition. FAO, Rome.

FAO, IFAD, WFP, 2015. The State of Food Insecurity in the World 2015. Meeting The 2015 International Hunger Targets: Taking Stock Of Uneven Progress. FAO, Rome.

Ferens, W.A., Hovde, C.J., 2011. Escherichia coli 0157:H7: animal reservoir and sources of human infection. Foodborne Pathog. Dis. 8, 465-487.

Fischer, J., Brosi, B., Daily, G.C., Ehrlich, P.R., Goldman, R., Goldstein, J., et al., 2008. Should agricultural policies encourage land sparing or wildlife-friendly farming? Front. Ecol. Environ. 6, 380-385.

Fletcher, J., Leach, J.E., Eversole, K., Tauxe, R., 2013. Human pathogens on plants: designing a multidisciplinary strategy for research. Phytopathology 103, 306-315.

Franz, E., Semenov, A.V., Termorshuizen, A.J., de Vos, O.J., Bokhorst, J.G., van Bruggen, A.H.C., 2008a. Manure-amended soil characteristics affecting the survival of E-coli 0157: H7 in 36 Dutch soils. Environ. Microbiol. 10, 313-327.

Franz, E., Semenov, A.V., van Bruggen, A.H.C., 2008b. Modelling the contamination of lettuce with Escherichia coli 0157:H7 from manure-amended soil and the effect of intervention strategies. J. Appl. Microbiol. 105, 1569-1584.

Gaukler, S.M., Linz, G.M., Sherwood, J.S., Dyer, N.W., Bleier, W.J., Wannemuehler, Y.M., et al., 2009. Escherichia coli, Salmonella, and Mycobacterium avium subsp. paratuberculosis in wild European starlings at a Kansas cattle feedlot. Avian Dis. $53,544-551$.

Green, K., Foster, C., 2005. Give peas a chance: transformations in food consumption and production systems. Technol. Forecast. Soc. Chang. 72, 663-679.

Gu, G., Cevallos-Cevallos, J.M., Vallad, G.E., van Bruggen, A.H.C., 2013. Organically managed soils reduce internal colonization of tomato plants by Salmonella enterica serovar Typhimurium. Phytopathology 103, 381-388.

Hamilton, A.J., Stagnitti, F., Premier, R., Boland, A.M., Hale, G., 2006. Quantitative microbial risk assessment models for consumption of raw vegetables irrigated with reclaimed water. Appl. Environ. Microbiol. 72, 3284-3290.

Hamilton, A.J., Burry, K., Mok, H.-F., Barker, S.F., Grove, J.R., Williamson, V.G., 2014. Give peas a chance? Urban agriculture in developing countries. A review. Agron. Sustain. Dev. 34, 45-73.

Haramoto, E.R., Gallandt, E.R., 2004. Brassica cover cropping for weed management: a review. Renew. Agric. Food Syst. 19, 187-198.

Hilborn, E.D., Mermin, J.H., Mshar, P.A., Hadler, J.L., Voetsch, A., Wojtkunski, C., et al., 1999. A multistate outbreak of Escherichia coli 0157: H7 infections associated with consumption of mesclun lettuce. Arch. Intern. Med. 159, 1758-1764.

Hill, S.R., MacRae, R.J., 1995. Conceptual framework for the transition from conventional to sustainable agriculture. J. Sustain. Agric. 7, 81-87.

Hodgson, J.A., Kunin, W.E., Thomas, C.D., Benton, T.G., Gabriel, D., 2010. Comparing organic farming and land sparing: optimizing yield and butterfly populations at a landscape scale. Ecol. Lett. 13, 1358-1367.

Hulme, M.F., Vickery, J.A., Green, R.E., Phalan, B., Chamberlain, D.E., Pomeroy, D.E., et al., 2013. Conserving the birds of Uganda's banana-coffee arc: land sparing and land sharing compared. PLoS One 8, e54597.

Hutchison, M.L., Walters, L.D., Avery, S.M., Synge, B.A., Moore, A., 2004. Levels of zoonotic agents in British livestock manures. Lett. Appl. Microbiol. 39, 207-214.

Igliński, B., Buczkowski, R., Iglińska, A., Cichosz, M., Piechota, G., Kujawski, W., 2012. Agricultural biogas plants in Poland: investment process, economical and environmental aspects, biogas potential. Renew. Sust. Energ. Rev. 16, 4890-4900.

Iniguez, A.L., Dong, Y.M., Carter, H.D., Ahmer, B.M.M., Stone, J.M., Triplett, E.W., 2005. Regulation of enteric endophytic bacterial colonization by plant defenses. Mol. PlantMicrobe Interact. 18, 169-178.

IPCC, 2012. In: Field, C.B., Barros, V., Stocker, T.F., Qin, D., Dokken, D.J., Ebi, K.L., et al. (Eds.), Managing the Risks of Extreme Events and Disasters to Advance Climate Change Adaptation. A Special Report of Working Groups I and II of the Intergovernmental Panel on Climate Change. Cambridge Univesity Press, Cambridge, UK, and New York, NY, USA, p. 582.

Jacobsen, S.E., Jensen, C.R., Liu, F., 2012. Improving crop production in the arid Mediterranean climate. Field Crop Res. 128, 34-47.

Jacxsens, L., Luning, P.A., van der Vorst, J.G.A.J., Devlieghere, F., Leemans, R., Uyttendaele, M., 2010. Simulation modelling and risk assessment as tools to identify the impact of climate change on microbiological food safety - the case study of fresh produce supply chain. Food Res. Int. 43, 1925-1935.

Jacxsens, L., Van Boxstael, S., Nanyunja, J., Jordaan, D., Luning, P., Uyttendaele, M., 2015. Opinions on fresh produce food safety and quality standards by fresh produce supply chain experts from the global south and north. J. Food Prot. 78, 1914-1924.

Jay, M.T., Cooley, M., Carychao, D., Wiscomb, G.W., Sweitzer, R.A., Crawford-Miksza, L., et al., 2007. Escherichia coli 0157: H7 in feral swine near spinach fields and cattle, central California coast. Emerg. Infect. Dis. 13, 1908-1911.

Jiménez, B., Asano, T., 2008. Water reclamation and reuse around the world. In: Jiménez, B., Asano, T. (Eds.), Water Reuse: An International Survey of Current Practice, Issues and Needs. IWA Publishing, London, p. 168.

Keraita, B., Konradsen, F., Drechsel, P., Abaidoo, R.C., 2007a. Effect of low-cost irrigation methods on microbial contamination of lettuce irrigated with untreated wastewater. Tropical Med. Int. Health 12, 15-22.

Keraita, B., Konradsen, F., Drechsel, P., Abaidoo, R.C., 2007b. Reducing microbial contamination on wastewater irrigated lettuce by cessation of irrigation before harvesting. Tropical Med. Int. Health 12, 8-14.

Keraita, B., Drechsel, P., Konradsen, F., 2008a. Using on farm sedimentation ponds to improve microbial quality of irrigation water in urban vegetable farming in Ghana. Water Sci. Technol. 57, 519-525.

Keraita, B., Drechsel, P., Konradsen, F., Vreugdenhil, R.C., 2008b. Potential of simple filters to improve microbial quality of irrigation water used in urban vegetable farming in Ghana. J. Environ. Sci. Health, Part A: Tox. Hazard. Subst. Environ. Eng. 43, 749-755.
Keraita, B., Jiménez, B., Drechsel, P., 2008c. Extent and implications of agricultural reuse of untreated, partly treated and diluted wastewater in developing countries. CAB Rev. Perspect. Agric. Vet. Sci. Nutr. Nat. Resour. 3, 1-15.

Klerks, M.M., Franz, E., van Gent-Pelzer, M., Zijlstra, C., van Bruggen, A.H.C., 2007. Differential interaction of Salmonella enteric serovars with lettuce cultivars and plantmicrobe factors influencing the colonization efficiency. ISME J. 1, 620-631.

Lahmar, R., Bationo, B.A., Lamso, N.D., Guero, Y., Tittonell, P., 2012. Tailoring conservation agriculture technologies to West Africa semi-arid zones: Building on traditional local practices for soil restoration. Field Crop Res. 132, 158-167.

Laidler, M.R., Tourdjman, M., Buser, G.L., Hostetler, T., Repp, K.K., Leman, R., et al., 2013. Escherichia coli 0157:H7 infections associated with consumption of locally grown strawberries contaminated by deer. Clin. Infect. Dis. 57, 1129-1134.

Lal, R., 2008. Sustainable horticulture and resource management. In: Prange, R.K., Bishop, S.D. (Eds.), Proc. XXVII IHC-S11 Sustain. through Integr. and Org. Hort. 767. Acta Horticulturae, pp. 19-43.

Lazarova, V., Asano, T., 2005. Challenges of sustainable irrigation with recycled water. In: Lazrova, V., Bahri, A. (Eds.), Water Reuse for Irrigation; Agriculture, Landscapes, and Turf Grass. CRC Press, London, pp. 1-30.

Leopoldo, O.R., Iturriaga, M.H., Tamplin, M.L., Fratamico, P.M., Call, J.E., Luchansky, J.B., et al., 2008. Animal and environmental impact on the presence and distribution of Salmonella and Escherichia coli in hydroponic tomato greenhouses. J. Food Prot. 71, $676-683$.

Levasseur, V., Pasquini, M.W., Kouamé, C., Temple, L., 2007. A Review of Urban and PeriUrban Vegetable Production in West Africa. In: Lumpkin, T.A., Warrington, I.J. (Eds.), Proc. XXVII IHC - Hort. Plants in Urban and Peri-Urban Life. 762Acta Hort. ISHS, pp. 245-252.

Liang, J.-Y., Chien, Y.-H., 2013. Effects of feeding frequency and photoperiod on water quality and crop production in a tilapia-water spinach raft aquaponics system. Int Biodeterior. Biodegrad. 85, 693-700.

Lohr, L., 2001. Factors affecting international demand and trade in organic food products. In: Regmi, A. (Ed.), Changing Structure of Global Food Consumption and Trade (WRS01-1). WRS-01-1. USDA Economic Research Service/WRS: International Agriculture and Trade Outlook, pp. 67-79.

Lynch, M.F., Tauxe, R.V., Hedberg, C.W., 2009. The growing burden of foodborne outbreaks due to contaminated fresh produce: risks and opportunities. Epidemiol. Infect. 137 307-315.

Maas, B., Clough, Y., Tscharntke, T., 2013. Bats and birds increase crop yield in tropical agroforestry landscapes. Ecol. Lett. 16, 1480-1487.

Marris, E., 2010. The vertical farm: feeding the world in the 21st century. Nature 468, 374

Martens, W., Bohm, R., 2009. Overview of the ability of different treatment methods for liquid and solid manure to inactivate pathogens. Bioresour. Technol. 100, 5374-5378.

McCullough, E.B., Pingali, P.L., Stamoulis, K.G., 2008. Small farms and the transformation of food systems: an overview. In: McCullough, E.B., Pingali, P.L., Stamoulis, K.G. (Eds.) The Transformation Of Agri-Food Systems. Globalization, Supply Chains And Smallholder Farmers. FAO and Earthscan, London, New York, pp. 3-46.

Mitra, R., Cuesta-Alonso, E., Wayadande, A., Talley, J., Gilliland, S., Fletcher, J., 2009. Effect of route of introduction and host cultivar on the colonization, internalization, and movement of the human pathogen Escherichia coli 0157:H7 in spinach. J. Food Prot 72, 1521-1530.

Molle, B., Brelle, F., Bessy, J., Gatel, D., 2012. Which water quality for which uses? Overcoming over-zealous use of the precautionary principle to reclaim wastewater for appropriate irrigation uses. Irrig. Drain. 61, 87-94.

Möller, K., Muller, T., 2012. Effects of anaerobic digestion on digestate nutrient availability and crop growth: A review. Eng. Life Sci. 12, 242-257.

Mshar, P.A., Dembek, Z.F., Cartter, M.L., Hadler, J.L., Fiorentino, T.R., Marcus, R.A., et al., 1997. Outbreaks of Escherichia coli O157:H7 infection and cryptosporidiosis associated with drinking unpasteurized apple cider - Connecticut and New York, October 1996 (Reprinted from MMWR, vol 46, pg 5-8, 1997). JAMA 277, 781-782.

Mukherjee, A., Speh, D., Dyck, E., Diez-Gonzalez, F., 2004. Preharvest evaluation of coliforms, Escherichia coli, Salmonella, and Escherichia coli 0157: H7 in organic and conventional produce grown by Minnesota farmers. J. Food Prot. 67, 894-900.

Mulder, K., Dube, B., 2014. Long-term ecological assessment of farming systems (LEAFS): comparing human, animal, and small machine power for fresh-market horticulture Agroecol. Sustain. Food Syst. 38, 704-721.

Nair, A., Ngouajio, M., 2012. Soil microbial biomass, functional microbial diversity, and nematode community structure as affected by cover crops and compost in an organic vegetable production system. Appl. Soil Ecol. 58, 45-55.

Narrod, C., Roy, D., Avendano, B., Okello, J., 2008. Impact of international food safety standards on smallholders: evidence from three cases. In: McCullough, E.B., Pingali, P.L., Stamoulis, K.G. (Eds.), The Transformation Of Agri-Food Systems. Globalization, Supply Chains And Smallholder Farmers. FAO and Earthscan, London, New-York, pp. 355-372.

Nienstedt, K.M., Brock, T.C.M., van Wensem, J., Montforts, M., Hart, A., Aagaard, A., et al., 2012. Development of a framework based on an ecosystem services approach for deriving specific protection goals for environmental risk assessment of pesticides. Sci. Total Environ. 415, 31-38.

Ottoson, J.R., Nyberg, K., Lindqvist, R., Albihn, A., 2011. Quantitative microbial risk assessment for Escherichia coli 0157 on lettuce, based on survival data from controlled studies in a climate chamber. J. Food Prot. 74, 2000-2007.

Ozores-Hampton, M., 2012. Developing a vegetable fertility program using organic amendments and inorganic fertilizers. HortTechnology 22, 743-750.

Paetzold, A., Warren, P.H., Maltby, L.L., 2010. A framework for assessing ecological quality based on ecosystem services. Ecol. Complex. 7, 273-281.

Pantaleo, A., De Gennaro, B., Shah, N., 2013. Assessment of optimal size of anaerobic codigestion plants: an application to cattle farms in the province of Bari (Italy) Renew. Sustain. Energy Rev. 20, 57-70. 
Version définitive du manuscrit publiée dans / Final version of the manuscript published in :

Science of the Total Environment (2016), Vol. 562, p. 751-759, DOI: 10.1016/j,scitotenv.2016.03.241

\section{Journal homepage : www.elsevier.com/locate/scitotenv}

Parish, M.E., 1998. Coliforms, Escherichia coli and Salmonella serovars associated with a citrus-processing facility implicated in a salmonellosis outbreak. J. Food Prot. 61, 280-284.

Park, S., Szonyi, B., Gautam, R., Nightingale, K., Anciso, J., Ivanek, R., 2012. Risk factors for microbial contamination in fruits and vegetables at the preharvest level: A systematic review. J. Food Prot. 75, 2055-2081.

Parker, J.S., Wilson, R.S., LeJeune, J.T., Doohan, D., 2012. Including growers in the "food safety" conversation: enhancing the design and implementation of food safety programming based on farm and marketing needs of fresh fruit and vegetable producers. Agric. Hum. Values 29, 303-319.

Petrea, S.M., Cristea, V., Dediu, L., Contoman, M., Lupoae, P., Mocanu, M., et al., 2013. Vegetable production in an integrated aquaponic system with rainbow trout and spinach. Bulletin of University of Agricultural Sciences and Veterinary Medicine Cluj-Napoca. Anim. Sci. Biotechnol. 70, 45-54.

Qadir, M., Bahri, A., Sato, T., Al-Karadsheh, E., 2010. Wastewater production, treatment, and irrigation in Middle East and North Africa. Irrig. Drain. Syst. 24, 37-51.

Quilliam, R.S., Williams, A.P., Jones, D.L., 2012. Lettuce cultivar mediates both phyllosphere and rhizosphere activity of Escherichia coli 0157:H7. PLoS One 7, e33842.

Ramos, R., Cerda-Cuellar, M., Ramirez, F., Jover, L., Ruiz, X., 2010. Influence of refuse sites on the prevalence of Campylobacter spp. and Salmonella serovars in seagulls. Appl. Environ. Microbiol. 76, 3052-3056.

Reardon, T., Timmer, C.P., Berdegue, J., 2008. The rapid rise of supermarket in developping countries: induced organizational, institutional and technological change in agri-food systems. In: McCullough, E.B., Pingali, P.L., Stamoulis, K.G. (Eds.), The Transformation Of Agri-Food Systems. Globalization, Supply Chains And Smallholder Farmers. FAO and Earthscan, London, New-York, pp. 47-65.

Reganold, J.P., Glover, J.D., Andrews, P.K., Hinman, H.R., 2001. Sustainability of three apple production systems. Nature 410, 926-930.

Rosen, J., 2012. Bug Problems? Call in the Chickens. Terra Magazine 2012; July 25th.

Ryals, R., Kaiser, M., Torn, M.S., Berhe, A.A., Silver, W.L., 2014. Impacts of organic matter amendments on carbon and nitrogen dynamics in grassland soils. Soil Biol. Biochem. 68, 52-61.

Sagoo, S.K., Little, C.L., Ward, L., Gillespie, I.A., Mitchell, R.T., 2003. Microbiological study of ready-to-eat salad vegetables from retail establishments uncovers a national outbreak of salmonellosis. J. Food Prot. 66, 403-409.

Semenov, A.V., van Overbeek, L., Termorshuizen, A.J., Van Bruggen, A.H.C., 2011. Influence of aerobic and anaerobic conditions on survival of Escherichia coli 0157:H7 and Salmonella enterica serovar Typhimurium in Luria-Bertani broth, farm-yard manure and slurry. J. Environ. Manag. 92, 780-787.

Singh, J.S., Pandey, V.C., Singh, D.P., 2011. Efficient soil microorganisms: a new dimension for sustainable agriculture and environmental development. Agric. Ecosyst. Environ. 140, 339-353.

Sivapalasingam, S., Friedman, C.R., Cohen, L., Tauxe, R.V., 2004. Fresh produce: a growing cause of outbreaks of foodborne illness in the United States, 1973 through 1997. J. Food Prot. 67, 2342-2353.

Smith-Spangler, C., Brandeau, M.L., Hunter, G.E., Bavinger, C., Pearson, M., Eschbach, P.J., et al., 2012. Are organic foods safer or healthier than conventional alternatives? Ann. Intern. Med. 157, 348-366.

Smukler, S.M., O'Geen, A.T., Jackson, L.E., 2012. Assessment of best management practices for nutrient cycling: a case study on an organic farm in a Mediterranean-type climate. J. Soil Water Conserv. 67, 16-31.
Soderstrom, A., Osterberg, P., Lindqvist, A., Jonsson, B., Lindberg, A., Ulander, S.B., et al., 2008. A large Escherichia coli 0157 outbreak in Sweden associated with locally produced lettuce. Foodborne Pathog. Dis. 5, 339-349.

Stagnitti, F., 1999. A model of the effects of nonuniform soil-water distribution on the subsurface migration of bacteria: implications for land disposal of sewage. Math. Comput. Model. 29, 41-52.

Stine, S.W., Song, I., Choi, C.Y., Gerba, C.P., 2005. Application of microbial risk assessment to the development of standards for enteric pathogens in water used to irrigate fresh produce. J. Food Prot. 68, 913-918.

Stuart, D., 2008. The illusion of control: industrialized agriculture, nature, and food safety. Agric. Hum. Values 25, 177-181.

Stuart, D., 2010. Coastal ecosystems and agricultural land use: new challenges on California's central coast. Coast. Manag. 38, 42-64.

United_Nations, 2015. Department of Economic and Social Affairs, Population division, world population prospects, the 2015 Revision. http://esa.un.org/unpd/wpp/ DataQuery/ (accessed 2016.03.29)).

USDA, 2010. In: Slattery, E., Livingston, M., Greene, C., Klonsky, K. (Eds.), Characteristics of conventional and organic apple production in the United States. Economic Research Service/USDA (FTS-347-01)

USDA, 2011. USDA Agroforestery Strategic Framework, Fiscal Year 2011-2016. June 2011. United States Department of Agriculture, p. 40

Uyttendaele, M., Jaykus, L.-A., Amoah, P., Chiodini, A., Cunliffe, D., Jacxsens, L., et al., 2015. Microbial hazards in irrigation water: standards, norms, and testing to manage use of water in fresh produce primary production. Compr. Rev. Food Sci. Food Saf. 14, 336-356.

van Elsas, J.D., Chiurazzi, M., Mallon, C.A., Elhottovā, D., Krištůfek, V., Salles, J.F., 2012. Microbial diversity determines the invasion of soil by a bacterial pathogen. Proc. Natl. Acad. Sci. 109, 1159-1164.

Van Rooijen, D., Biggs, T., Smout, I., Drechsel, P., 2010. Urban growth, wastewater production and use in irrigated agriculture: a comparative study of Accra, Addis Ababa and Hyderabad. Irrig. Drain. Syst. 24, 53-64.

Vaughn, S.F., Boydston, R.A., 1997. Volatile allelochemicals released by crucifer green manures. J. Chem. Ecol. 23, 2107-2116.

Wallach, R., Ben-Arie, O., Graber, E.R., 2005. Soil water repellency induced by long-term irrigation with treated sewage effluent. J. Environ. Qual. 34, 1910-1920.

WCED, 1986. Report of the Advisory Panel on Food Security, Agriculture, Forestry and Development. In: WCED G, CH (Eds.), WCED archive collection vol. 13 (doc. 95).

Weis, J., Seeliger, H.P.R., 1975. Incidence of Listeria monocytogenes in nature. Appl. Microbiol. 30, 29-32.

WHO, 2006. WHO guidelines for the safe use of wastewater, excreta and greywater/ World Health Organization. v. 2. Wastewater use in agriculture.

Williams, M.L., Pearl, D.L., LeJeune, J.T., 2011. Multiple-locus variable-nucleotide tandem repeat subtype analysis implicates European starlings as biological vectors for Escherichia coli 0157:H7 in Ohio, USA. J. Appl. Microbiol. 111, 982-988.

Wolf, M., 2015. Is there really such a thing as "one health"? Thinking about a more than human world from the perspective of cultural anthropology. Soc. Sci. Med. 129, 5-11.

Wright, I.A., Tarawali, S., Blummel, M., Gerard, B., Teufel, N., Herrero, M., 2012. Integrating crops and livestock in subtropical agricultural systems. J. Sci. Food Agric. 92, 1010-1015. 